\title{
A NOTE ON THE CHANGES IN WATER CONTENT OF THE LOBSTER (HOMARUS VULGARIS M.-EDW.) DURING MOULT
}

\author{
By A. G. Lowndes and N. K. Panikkar \\ From the Plymouth Laboratory
}

One of the lobsters kept in the tanks of the Plymouth Laboratory moulted on the night of 20 August 1940. This opportunity was taken to examine the changes in water content and osmotic pressure of the freshly moulted as compared with unmoulted lobsters. Though only one recently moulted individual has been examined, the results seem to be worthy of note since so far as we are aware no data are available on the subject in regard to Homarus. The biology of moulting among lobsters has received the attention of many investigators (vide Herrick (1895) and Drach (1939) for summary and literature).

The water content was determined by distilling the fresh lobster together with a known weight of sea water under xylol. This method is a modification of that of Dean and Stark which one of us (A. G. L.) has tried on a number of animals and found to give accurate results. The density was estimated by a modification of a method previously described (Lowndes, 1938). Osmotic pressure of blood and the external medium were measured by Baldes's (1934) modification of the Hill thermoelectric technique, as employed by one of us (N. K. P.) in the study of prawns and other crustaceans. The water content of the moulted skin was calculated from its dry weight taken after dehydrating in a hot air oven for $48 \mathrm{hr}$. at $105^{\circ} \mathrm{C}$. Osmotic pressure was measured $\mathrm{I} 7 \pm 6 \mathrm{hr}$. after moult; density and water content after $34 \pm 6 \mathrm{hr}$. The temperature of sea water at which the density was estimated was $17^{\circ} \mathrm{C}$. Both lobsters were 4-5 years old as judged by Elmhirst's (1930) growth curve. The results obtained are given in Table I.

The higher values for density and sinking factor are just what one would expect from the highly calcified exoskeleton in the lobster of late intermoult phase. Homarus is a stenohaline invertebrate which is isotonic with its surroundings and it is interesting to note that more or less the same degree of osmotic equilibrium with the surroundings is observed in less than one day after moult. Hence, if there is any rapid rise in osmotic pressure prior to moult, as has been observed in some Crustacea, this anisotonicity disappears soon after moulting. The values of water content indicate that a lobster of fresh weight $100 \mathrm{~g}$. loses about $28 \mathrm{~g}$. when its skin is shed, and that it absorbs about $47 \mathrm{~g}$. of water within $34 \pm 6 \mathrm{hr}$. after moulting. Thus an increase in 
weight of $19 \%$ is observed in so short a period. Elmhirst(1930) has shown that this increase in weight during the post-moult phase may be as high as $38 \%$,

\section{TABLE I}

\begin{tabular}{|c|c|c|c|c|c|}
\hline & & $\begin{array}{l}\text { Density } \\
\text { g. per ml. }\end{array}$ & $\begin{array}{l}\text { Sinking } \\
\text { factor }\end{array}$ & $\begin{array}{l}\text { Osmotic } \\
\text { pressure } \\
\text { of blood } \\
\% \mathrm{NaCl}\end{array}$ & $\begin{array}{l}\text { Osmotic } \\
\text { pressure } \\
\text { of medium } \\
\% \mathrm{NaCl}\end{array}$ \\
\hline $\begin{array}{l}\text { Soft lobster, } \\
\text { Hard lobster, } \\
\text { (late intermou }\end{array}$ & & $\begin{array}{l}\mathrm{I} \cdot 077 \\
\mathrm{I} \cdot \mathrm{I} 58\end{array}$ & $\begin{array}{l}\text { IO50 } \\
\text { I I } 28\end{array}$ & $\begin{array}{l}3.410 \\
3.403\end{array}$ & $\begin{array}{l}3.338 \\
3.346\end{array}$ \\
\hline Lobster & $\begin{array}{l}\text { Volume } \\
\text { ml. }\end{array}$ & $\begin{array}{c}\text { Gross weight } \\
\text { g. }\end{array}$ & $\begin{array}{l}\text { Wt. of water } \\
\text { g. }\end{array}$ & $\%$ water & $\begin{array}{c}\% \text { water } \\
\text { including } \\
\text { moulted skin }\end{array}$ \\
\hline oft $:$ q after moult & I IO.02 & II 8.47 & $97 \cdot 43$ & $82 \cdot 24 !$ & \\
\hline $\begin{array}{l}\text { ulted skin alone } \\
\text { d: late }\end{array}$ & $\overline{2}$ & $45 \cdot \mathrm{I} 4$ & $29 \cdot 04$ & & $77 \cdot 30$ \\
\hline & I36.I3 & I57.61 & $105 \cdot 16$ & & 66.68 \\
\hline
\end{tabular}

$\star$ Sinking factor $=\frac{\text { Density of organism }}{\text { Density of medium }} \times 10^{3}$.

It may be seen from these figures that:

The amount of water in a lobster of dry weight $33.32 \mathrm{~g}$. after moult

$$
=\frac{33.32 \times 77.3}{22.7}=113.5 \mathrm{~g} \text {. }
$$

Therefore the amount of water absorbed $=113 \cdot 5-66 \cdot 68=46 \cdot 82 \mathrm{~g}$.

but it may be noted that the post-moult phase during which it takes place lasts from 15 to 30 days.

\section{REFERENCES}

BALdes, E. J., I934. A micromethod of measuring osmotic pressure. fourn. Sci. Instr., Vol. XI, pp. 223-5.

Drach, P., I939. Mue et cycle d'intermue chez les Crustacés Décapodes. Ann. Inst. Oceanogr. Monaco, Vol. xIx, pp. I03-39I.

ELMHIRST, R., 1930. An interim report of the interdepartmental committee on crabs and lobsters, pp. I-I2. London (H.M. Stat. Office).

HerRICK, F. H., I895. The American Lobster: a study of its habits and development. Bull. U.S. Fish Comm., No. xv, pp. I-252.

Lowndes, A. G., I938. The density of some living aquatic organisms. Proc. Linn. Soc., Sess. I50, pp. 62-73. 